\title{
EDITORIAL
}

\section{Covid and Clots in Veins: What's Best to do}

University Heart Journal 2022; 18(1): 1-2

Severe acute respiratory syndrome coronavirus 2(SARSCoV-2) infection is associated with increased risk of arterial and venous thrombotic complications. In a US registry of patients with coronavirus disease 2019 (COVID-19), thrombotic complications occurred in 2.6\% of 229 non-critically ill hospitalized patients and in 35.3\% of 170 hospitalized critically ill patients. ${ }^{1}$ The risk of thromboembolism in SARS-CoV-2 infection in nonhospitalized patients is not known.

Although the pathophysiology behind increased thromboembolism is not fully defined, COVID-19 infection is associated with abnormalities in all 3 parts of Virchow's triad and hence there exists a pathophysiological rationale for an increased risk of VTE.

-First, endothelial dysfunction may develop due to direct viral invasion of endothelial cells via Angiotensin Converting Enzyme-2 (ACE2), or as a result of the subsequent marked inflammatory response and tissue hypoxia. ${ }^{2,3}$

-Second, COVID-19 induces a pro-coagulant state with an increase in factors V, VII, VIII and X and von Willebrand factor and a reduction in ADAMTS13 levels. ${ }^{4,5}$ High levels of antiphospholipid antibodies have also been reported, although their clinical significance is uncertain. ${ }^{6,7}$ Furthermore, reduced fibrinolysis resulting from increased plasminogen activator inhibitor 1 has been observed in intensive care unit (ICU) and non-ICU patients. ${ }^{8,9}$ In addition, platelet activation may also increase the risk of VTE. ${ }^{10}$

-Third, immobility and resultant venous stasis is common, especially in more severe COVID-19 disease.

D-Dimers levels are frequently elevated in patients with COVID-19 and are prognostic. High levels may arise as a result of thrombosis or inflammation. Current data do not support the routine use of high D-Dimer levels in isolation to guide decisions regarding investigation and anticoagulation; levels should be assessed within the overall clinical context. ${ }^{11}$

Pulmonary thromboembolic disease should be considered in patients with hypoxaemia disproportionate to X-Ray changes or sudden worsening of blood pressure, heart rate or oxygen requirements.
All patients admitted with COVID-19 should be assessed for, and the majority receive, thromboprophylaxis. Although multiple trials testing interventions to prevent thrombotic complications in COVID-19 are underway, current clinical guide-lines have relied on previous studies of VTE prophylaxis in acute non-COVID-19 medical illness. Therapeutic LMWH should be considered for inpatients with Covid-19 disease who are managed on general wards and require supplemental oxygen. ${ }^{11}$ Patients with no evidence of VTE or other indication for therapeutic anticoagulation who require high-flow oxygen, CPAP, NIV for severe ventilatory failure or invasive ventilation should receive less than therapeutic dosing. ${ }^{11}$ The published evidence would suggest no benefit of intermediate over standard dose thromboprophylaxis in these patients. Bleeding risk should be considered when making decisions regarding intensity of anticoagulation. ${ }^{11}$

There are no specific RCT data to guide the optimal duration of thromboprophylaxis in patients recovering from moderate or severe COVID-19. ${ }^{11}$ A number of observational studies have reported low incidences of acute VTE following hospital discharge of $0-0.6 \%$ which do not appear to be greater than in non-Covid-19 patients. ${ }^{12,13} \mathrm{ACCP}$ does not recommend post discharge thromboprophylaxis. ${ }^{14}$ In contrast, the ISTH recommends post discharge thromboprophylaxis with LMWH or a DOAC for all high-risk hospitalized patients with COVID19 who have a low risk of bleeding. ${ }^{15}$ The ISTH suggests a duration of 14 to 30 days for post discharge thromboprophylaxis, although optimal duration remains unclear. ${ }^{15}$ Thromboprophylaxis for patients who do not require hospitalization is not currently recommended.

${ }^{1}$ Dipal Krishna Adhikary, Associate Professor, Department of Cardiology, Bangabandhu Sheikh Mujib Medical University (BSMMU), Dhaka

${ }^{2}$ Mohammad Walidur Rahman, Assistant Registrar, Department of Cardiology, National Institute of Cardiovascular Disease (NICVD), Dhaka

\section{References:}

1. Piazza G, Campia U, Hurwitz S, et al. Registry ofarterial and venous thromboembolic complicationsin patients with COVID19.J Am Coll Cardiol.2020;76(18):2060-2072. doi:10.1016/ j.jacc.2020.08.070 
2. Loo J, Spittle DA and Newnham M. COVID-19, immunothrombosis and venous thromboembolism: biological mechanisms. Thorax. 2021.

3. Talasaz AH, Sadeghipour P, Kakavand H, Aghakouchakzadeh M, Kordzadeh-Kermani E, Van Tassel B, Gheymati A, Ariannejad H, Hosseini SH, Jamalkhani S, Sholzberg M, Monreal M, Jimenez D, Piazza G, Parikh SA, Kirtane A, Eikelboom JW, Connors JM, Hunt BJ, Konstantinides S, Cushman M, Weitz JI, Stone GW, Krumholz HM, Lip GY, Goldhaber SZ and Bikdeli B. Antithrombotic Therapy in COVID-19: Systematic Summary of Ongoing or Completed Randomized Trials. medRxiv preprint. 2021:doi.org/10.1101/2021.01.04.21249227.

4. Stefely JA, Christensen BB, Gogakos T, Cone Sullivan JK, Montgomery GG, Barranco JP and Van Cott EM. Marked factor $\mathrm{V}$ activity elevation in severe COVID-19 is associated with venous thromboembolism. Am J Hematol. 2020;95:1522-30.

5. Mancini I, Baronciani L, Artoni A, Colpani P, Biganzoli M, Cozzi G, Novembrino C, BoscoloAnzoletti M, De Zan V, Pagliari MT, Gualtierotti R, Aliberti S, Panigada M, Grasselli G, Blasi F and Peyvandi F. The ADAMTS13-von Willebrand factor axis in COVID-19 patients.J ThrombHaemost. 2020.

6. Zhang Y, Xiao M, Zhang S, Xia P, Cao W, Jiang W, Chen H, Ding X, Zhao H, Zhang H, Wang C, Zhao J, Sun X, Tian R, Wu W, Wu D, Ma J, Chen Y, Zhang D, Xie J, Yan X, Zhou X, Liu Z, Wang J, Du B, Qin Y, Gao P, Qin X, Xu Y, Zhang W, Li T, Zhang F, Zhao Y, Li Y and Zhang S. Coagulopathy and Antiphospholipid Antibodies in Patients with Covid-19. N Engl J Med. 2020.

7. Borghi MO, Beltagy A, Garrafa E, Curreli D, Cecchini G, Bodio C, Grossi C, Blengino S, Tincani A, Franceschini F, Andreoli L, Lazzaroni MG, Piantoni S, Masneri S, Crisafulli F, Brugnoni D, Muiesan ML, Salvetti M, Parati G, Torresani E, Mahler M, Heilbron F, Pregnolato F, Pengo M, Tedesco F, Pozzi N and Meroni PL. Anti-Phospholipid Antibodies in COVID-19 Are Different From Those Detectable in the Anti-Phospholipid Syndrome. Front Immunol. 2020;11:584241.

8. Goshua G, Pine AB, Meizlish ML, Chang CH, Zhang H, Bahel P, Baluha A, Bar N, Bona RD, Burns AJ, Dela Cruz CS, Dumont A, Halene S, Hwa J, Koff J, Menninger H, Neparidze N, Price C,
Siner JM, Tormey C, Rinder HM, Chun HJ and Lee AI. Endotheliopathy in COVID-19-associated coagulopathy: evidence from a single-centre, cross-sectional study. Lancet Haematol. 2020;7:e575-e582.

9. Guan WJ, Ni ZY, Hu Y, Liang WH, Ou CQ, He JX, Liu L, Shan H, Lei CL, Hui DSC, Du B, Li LJ, Zeng G, Yuen KY, Chen RC, Tang CL, Wang T, Chen PY, Xiang J, Li SY, Wang JL, Liang ZJ, Peng YX, Wei L, Liu Y, Hu YH, Peng P, Wang JM, Liu JY, Chen Z, Li G, Zheng ZJ, Qiu SQ, Luo J, Ye CJ, Zhu SY, Zhong NS and China Medical Treatment Expert Group for C. Clinical Characteristics of Coronavirus Disease 2019 in China. N Engl J Med. 2020.

10. Manne BK, Denorme F, Middleton EA, Portier I, Rowley JW, Stubben C, Petrey AC, Tolley ND, Guo L, Cody M, Weyrich AS, Yost CC, Rondina MT and Campbell RA. Platelet gene expression and function in patients with COVID-19. Blood. 2020;136: 1317-29.

11. BTS Guidance on Venous Thromboembolic Disease in patients with COVID-19V4.0 31 August 2021

12. Roberts LN, Whyte MB, Georgiou L, Giron G, Czuprynska J, Rea C, Vadher B, Patel RK, Gee E and Arya R. Postdischarge venous thromboembolism following hospital admission with COVID-19. Blood. 2020;136:1347-50.

13. Bertoletti L, Bikdeli B, Zuily S, Blondon M and Mismetti P. Thromboprophylaxis strategies to improve the prognosis of COVID-19. VasculPharmacol. 2021;139:106883.

14. Moores LK, Tritschler T, Brosnahan S, et alPrevention, diagnosis and treatment of venousthromboembolism in patients with COVID-19:CHEST Guideline and Expert Panel Report. Chest.2020;158:1143-1163. doi:10.1016/j.chest.2020.05.559

15. Spyropoulos AC, Levy JH, Ageno W, et al;Subcommittee on Perioperative, Critical CareThrombosis, Haemostasis of the Scientific,Standardization Committee of the InternationalSociety on Thrombosis and Haemostasis. Scientificand Standardization Committee communication:Clinical guidance on the diagnosis, prevention, andtreatment of venous thromboembolism inhospitalized patients with COVID-19.J ThrombHaemost. 2020;18(8):1859-1865. doi:10.1111/jth.14929 